Maciej Ostrowski ${ }^{1}$

Uniwersytet Papieski Jana Pawła II w Krakowie

\title{
Młodzież w oczach papieży na podstawie przemówień podczas Światowych Dni Młodzieży
}

Młodzież stoi w centrum zainteresowania wielu środowisk i badaczy. Ona buduje przyszłość. Zjawiska widoczne wśród młodych mają wpływ na szerokie kręgi społeczne i całe narody. Jak papieże naszej doby widzą młodzież świata? Jakie zjawiska budzą nadzieję, a jakie zatroskanie i niepokój. Jan Paweł II często powtarzał, że młodzież jest jego nadzieją, nadzieją świata i Kościoła. 0 młodzieży i do młodzieży wiele razy mówili jego następcy: Benedykt XVI i Franciszek. Trudno byłoby w krótkim artykule ogarnąć obszerne treści papieskich tekstów skierowanych do młodzieży. W związku ze Światowymi Dniami Młodzieży w Krakowie ukazał się zbiór listów, orędzi, przemówień i homilii trzech papieży. Liczy on 600 stron $^{2} \mathrm{i}$ jest podstawą do wieloaspektowych stu-

1 Ks. prof. zw. dr hab. Maciej Ostrowski, kierownik Katedry Teologii Pastoralnej oraz dyrektor Instytutu Teologii Praktycznej WT UPJPII w Krakowie; sekretarz Rady Episkopatu Polski ds. Migracji, Turystyki i Pielgrzymek; specjalizuje się w problematyce pastoralnej z zakresu wolnego czasu, turystyki, pielgrzymowania, migracji, ekologii, parafii i ugrupowań kościelnych. E-mail: maciej.ostrowski@upjp2.edu.pl.

2 Święty Jan Paweł II, Benedykt XVI, Franciszek, Do młodzieży (1979-2015). Listy, orędzia, przemówienia, homilie, Poznań 2015. W niniejszym artykule dla uproszczenia zamiast przypi- 
diów i wielu szczegółowych prac. Równocześnie minęło 30 lat, od kiedy Jan Paweł II zainicjował Światowe Dni Młodzieży. To dobra okazja, by przyjrzeć się treściom przesłania papieży do młodych. Autor artykułu - mając świadomość obszerności tematu - chciałby wskazać jedynie na kilka jego wątków: ograniczyć się najpierw do Światowych Dni Młodzieży organizowanych w różnych miastach świata z obecnością papieży. Nie chodzi zatem o Dni, które odbywały się w innych latach, równocześnie w całym Kościele, we wszystkich diecezjach. Dalej: ograniczyć się do głównych papieskich przemówień wygłoszonych podczas szczytowych celebracji Światowych Dni Młodzieży. Było ich trzynaście ${ }^{3}$. Pojawia się jednak pewien problem, które z przesłań uznać za takie. Nie wszystkie Dni miały identyczny przebieg. Składały się nań różne elementy: czuwania, adoracje, drogi krzyżowe, spotkania na Anioł Pański, spotkania z wolontariuszami. Zwykle jednak odbywała się główna msza święta na zakończenie, podczas której papieże wygłaszali homilie do młodych, które mogły być potraktowane jako ich przewodnie przesłanie. Oczywiście trzeba będzie odnieść się do innych papieskich wystąpień, jak również do orędzi przygotowujących światowe spotkania. Z pewnością ciekawe byłoby porównanie spojrzenia trzech różnych papieży oraz ewolucji ich poglądów. Ramy artykułu nie pozwalają na pogłębienie tych aspektów.

Papieże nie dokonują zasadniczo i wprost opisu sytuacji współczesnej młodzieży ani nie koncentrują się na charakterystyce tego środowiska. Pokazują natomiast młodym pewne wybrane prawdy jej dotyczące, jak też charakteryzują ważne zadania przed nią stojące. Z pewnością dobór zagadnień poruszanych przez papieży nie jest przypadkowy - stanowi odpowiedź na palące problemy młodzieżowego środowiska. W ten spo-

sów dolnych będziemy podawać przypisy wtrącone w nawiasie. Użyjemy nazw miejsc ŚDM i roku ich odbycia. Odnoszą one do tekstów przemówień papieskich na zakończenie kolejnych Dni zawartych w zacytowanej publikacji.

3 Rzym - 1985, Buenos Aires - 1987, Santiago de Compostela - 1989, Częstochowa - 1991, Denver - 1993, Manila - 1995, Paryż - 1997, Rzym - 2000, Toronto - 2002, Kolonia - 2005, Sydney - 2008, Madryt - 2011, Rio de Janeiro - 2013. W całości Światowych Dni Młodzieży było dwadzieścia dziewięć. Jak wskazano naprzemiennie, we wszystkich diecezjach świata i wspólnie z papieżem w wybranym mieście. W Krakowie, w 2016 roku, odbyły się trzydzieste Dni. 
sób, pośrednio, można wnioskować, jak papieże widzą współczesną młodzież. Analizując wnikliwie papieskie przemówienia, można dostrzec opis współczesnego świata, w którym żyje młodzież. Młode pokolenie jest częścią społeczności świata. W nim jak w zwierciadle odbijają się problemy dzisiejszych społeczeństw. Świat jest pełen niepokojących i negatywnych zjawisk. Tego papieże nie ukrywają; przykładowo zagubienia wiary w Boga, materializmu, egoizmu, moralnego permisywizmu, nietolerancji, przemocy, panoszącej się kultury śmierci, kryzysu rodzin, ubóstwa, barier dzielących ludzi między sobą itd. Młode pokolenie chrześcijan jest poniekąd także odbiciem niepokojących zjawisk w samym Kościele. Papieże wskazują na mało dynamiczną wiarę, zamykanie się w gronie wierzących i brak wyjścia z Ewangelią ku drugim. Owa prezentacja słabości świata i Kościoła bynajmniej nie przeważa w tonie przemówień. Papieże rysują w nich zadania stojące przed młodzieżą. Ich konsekwentna realizacja przyczyni się do umocnienia środowiska młodych i do jego dojrzałości. Nie jest to zatem narzekanie, moralizowanie, przestrzeganie przed złem, a zatem negatywne podejście. Natomiast spojrzenie z nadzieją na zwycięstwo dobra i siły chrześcijańskiej wiary, którą nosi w sobie młode pokolenie; ostatecznie na zwycięstwo Chrystusa. W papieskich wypowiedziach przeważa zatem ton pozytywny i optymistyczny. Papieże widzą w młodych wiele dynamizmu, entuzjazmu i zapału. Ufają, że młodzież będzie mogła zmienić ten świat, ale tylko wtedy, gdy sama zwróci się do Chrystusa i zwiąże się z Nim przyjaźnią. Zapraszają młodych, by oddali swe zdolności i entuzjazm na rzecz pozytywnej przemiany świata. Jeśli pojawia się wątek krytyczny, to pozostaje on w tle wypowiedzi. Papieże chcą raczej pokazać drogi umacniania postaw pozytywnych, wypływających z wiary, by one stawały się antidotum na zło w świecie.

W każdym z przemówień papieskich można znaleźć odniesienie do lokalnych problemów. Trzeba pamiętać, że przesłania te były wygłaszane w różnych, bardzo odległych zakątkach świata. Pojawiały się w nich inne, lokalne problemy, np. brak poszanowania praw pewnych grup społecznych, wybujały materializm, zatracenie poczucia świętości niedzieli, zatracenie potrzeby sakramentu pojednania, kryzys życia kościelnego, a nawet odrzucenie samego Kościoła. Równocześnie jednak były to prze- 
słania uniwersalne, dotyczące całego ziemskiego globu. Przy dzisiejszej globalizacji i ciągle rosnących możliwościom komunikacyjnym wiele zjawisk przenosi się szybko na coraz to nowsze obszary.

Analizując papieskie wskazania, mając w świadomości szybko zmieniający się i trudny świat, można by w kwestii skutecznego głoszenia Ewangelii spodziewać się rozwiązań nadzwyczajnych, dotąd niespotykanych. Tymczasem papieże wracają do spraw prostych i elementarnych, które według nich są niezastąpionym fundamentem dla chrześcijan, katolików: modlitwy, zgłębiania Pisma Świętego, poznawania katechizmu, miłości do Eucharystii, odkrywania na nowo sakramentu pokuty. Przede wszystkim zaś zachęcają do ożywiania więzi z Chrystusem i otwierania się na moc Ducha Świętego 4 .

Papieskie przesłania na Światowe Dni Młodzieży powstawały na przestrzeni trzydziestu lat. Wydawałoby się, że będą ewoluować i wzbogacać się we wciąż nowe treści. Tymczasem powracają w nich wciąż te same wątki. Nie należy sądzić, by papieże nie mieli rozeznania w dynamicznej sytuacji młodzieży. W oczach papieży te, zdawałoby się, nowe problemy dają się sprowadzić do kilku fundamentalnych spraw, które są niezmienne. Tak naprawdę ich istota jest ta sama. Zmienia się jedynie zewnętrzny kształt. Człowiek, także młody, boryka się w każdym czasie z tymi samymi zagadnieniami, choć ich chwilowe formy mogą się od siebie różnić. Pośrednio jest to potwierdzeniem prawdy, że choć świat zmienia się szybko, Ewangelia i jej wskazania pozostają niezmienne. Są dla człowieka stałym drogowskazem.

\section{Osobista relacja z Chrystusem}

Najczęściej bodajże przewijającym się wątkiem w papieskich przemówieniach jest sprawa osobistej relacji młodych do Chrystusa. Papieże zadają pytanie: kim jest dla ciebie Chrystus? Zachęcają, by poznać pełną

4 Można tu przeprowadzić porównanie z duszpasterskimi priorytetami wskazanymi przez Jana Pawła II w jego liście na początek nowego tysiąclecia Novo millenio ineunte (rozdział III). 
prawdę o Nim, szczególnie miłość, którą nas obdarza (Rzym 2000, Buenos Aires 1987, Madryt 2011), a przede wszystkim nawiązać z Nim bardzo intymne więzi. Wzywają młodych do zaprzyjaźnienia się z Chrystusem i bardziej jeszcze zdecydowanego pójścia za Nim, bo tylko On jest prawdziwym przyjacielem, który nie zawiedzie. Mobilizują do budowania swego życia w oparciu o Jego wzorzec (Manila 1995, Kolonia 2005).

Jak wiemy, wiara nie jest tylko uznaniem pewnej liczby prawd objawionych przez Boga, a nawet akceptacją samego istnienia Boga, ale zawierzeniem Jemu jako osobie. Jest dialogiem z Bogiem, kiedy to człowiek odpowiada swoją miłością na miłość Boga ${ }^{5}$. Jak powiedział Benedykt XVI, u początku wiary nie ma spotkania z jakąś ideą, ale jest spotkanie z osobą Boga ${ }^{6}$. Jednym z braków, który dotykał w przeszłości i nadal dotyka chrześcijan, jest tzw. wiara z tradycji, związana bardziej ze społecznymi uwarunkowaniami. Z takiego podejścia wynika słabe zakorzenienie się w wierze, a co za tym idzie łatwe uleganie kryzysom wiary. Jak się zdaje, przynajmniej ostatnie wieki chrześcijaństwa bardziej zwracały uwagę na intelektualny przekaz wiary, zarazem eksponując jej moralne konsekwencje, mniej natomiast akcentowały osobisty akt zawierzenia Bogu. Stąd w wielu regionach świata w sytuacji światopoglądowego zamieszania obserwuje się kryzys wiary ${ }^{7}$. Papieże ostatnich dekad powtarzają wezwanie do ewangelizacji skierowanej ku samym chrześcijanom, by obudzić ich osobistą relację z Bogiem. Benedykt XVI zachęcał młodych do ożywienia życia sakramentalnego, zwłaszcza Eucharystii, poprzez które spotykają się oni z żywym i aktualnie obdarzającym łaską Chrystusem (Kolonia 2005, Toronto 2002). Dla młodych owo mocne zakorzenienie się w Chrystusie na początku ich życiowej drogi będzie miało pozytywny wpływ i konsekwencje na całe ich dalsze lata. Benedykt XVI wyraźnie powiedział do młodzieży, że wiara nie jest zestawem pewnych informacji, ale osobistą więzią, przylgnięciem do Chrystusa (Madryt 2011). A Jan Paweł II podkreślał, że przyjmując wiarę, nie przyjmujemy „czegoś”, czyli jakiegoś zestawu prawd bądź wzniosłych zasad moral-

Por. np. Katechizm Kościoła Katolickiego, 150, 154.

Benedykt XVI, enc. Deus caritas est, 1.

Por. F. Blachnicki, Teologia pastoralna ogólna, Warszawa 2013, s. 192-196. 
nych, lecz samą osobę Boga, z którym mamy pozostawać w żywym kontakcie (Rzym 2000).

„Rynek” propozycji światopoglądowych jest we współczesnym świecie bardzo szeroki. Stąd może się zdarzyć, że wielu młodych ma wypaczony obraz Chrystusa. Widzi w Nim jedynie wielkiego człowieka, genialnego przywódcę, nauczyciela, nie dostrzegając, że jest On najpierw Bogiem, odkupicielem i zbawicielem całego świata oraz każdego z osobna człowieka (Rzym 1985, Buenos Aires 1987, Manila 1995). Stąd też trzeba poznawać Chrystusa nie tylko jako autorytet, a nawet wielką postać religijnego przywódcy, jakich było wielu w historii, ale przede wszystkim jako przyjaciela oraz nawiązać z nim żywy kontakt. Wiara bowiem, jak podkreśliliśmy przed chwilą, nie daje tylko pewnych informacji, ale jest osobistą więzią z Bogiem, przylgnięciem do Chrystusa (Madryt 2011). Ten Chrystus jest Bogiem i może dać człowiekowi życie wieczne, które nieskończenie przekracza to, co ziemskie.

Być może wielu młodych wypaczyło w sobie obraz Chrystusa z powodu przykrych sytuacji, które zaobserwowali w Kościele. Ulegli sugestiom kręgów, które błędnie postrzegają chrześcijaństwo. Tak jak za czasów św. Pawła uważają je za słabość i „głupstwo” (1 Kor 1, 18-20). Stąd wezwanie papieży do odkrycia na nowo Chrystusa i poznania jego prawdziwego obrazu. Zapewnienie, że nie tylko nie zawiodą się na Nim, ale dzięki Niemu zwyciężą problemy, lęki, wątpliwości, które wokół nich narastają. On jest prawdą, która nadaje sens wszystkim zmaganiom młodego wieku. On daje prawdziwą mądrość i przywraca sens życia (Manila 1995, Paryż 1997).

Wielu z młodych być może zatraciło radość wiary. Często dzieje się tak, gdy człowiek postrzega wiarę jedynie jako zestaw zakazów i nakazów, a nie jako fascynującą przyjaźń oraz bliską więź z Bogiem. Papież Franciszek przypomina młodym, że owo przyjacielskie, intymne spotkanie z Jezusem pozwala doświadczyć radości wiary (Rio 2013) ${ }^{8}$.

Przyjaźń z Chrystusem, o której tak często wspominają papieże, wymaga Jego naśladowania w konkretnych uczynkach. Z niej zrodzi się potrzeba radosnego dzielenia z innymi swoją wiarą (Madryt 2011). o tej sprawie

8 Por. Franciszek, adhort. apost. Evangelii gaudium, zwłaszcza 2-7. 
wspomnimy za chwilę. Reasumując obecny paragraf, nie można oprzeć się stwierdzeniu, że w poruszonym wątku Światowych Dni Młodzieży wyraźnie brzmi echo programowych wezwań pontyfikatu św. Jana Pawła „Otwórzcie drzwi Chrystusowi" , „Jeden zwrot ducha, jeden kierunek umysłu, woli i serca: ad Christum Redemptorem hominis ${ }^{10}$.

\section{Wiara}

O wierze powiedzieliśmy już kilka słów w poprzednim paragrafie. Znajduje ona fundament w osobistej relacji do Chrystusa. Papieże, mimo obserwowanego w świecie kryzysu chrześcijaństwa, widzą w młodych ludziach wiarę. Jan Paweł II jest wręcz przekonany o „głębokim i przejmującym" doświadczeniu wiary młodego pokolenia. I bynajmniej nie uważa tego za czczą pochwałę. Obserwuje, że młodzi otworzyli się na prawdę Chrystusa i obietnicę nowego życia, które im daje. Młodzież szuka Boga i nosi w sobie pragnienie Boga. Szuka ponadczasowego sensu swej egzystencji. Jest to dla niej charakterystyczne. Wielu młodych chętnie korzysta z sakramentów, zwłaszcza pokuty i Eucharystii, chętnie się modli. Jest to rzeczywiste doświadczenie młodych. Jan Paweł II widzi, że ta jedna wiara jednoczy młodzież całego świata i ma pozytywny wpływ na tworzenie jedności w całym świecie, „budowanie wspólnego domu” (Częstochowa 1991, Denver 1993).

Jednakże papieże zauważają, że wielu młodych na świecie zagubiło wiarę, a co się z tym wiąże - sens życia. Jest to zjawisko dotykające całych społeczeństw. Wywołuje ono duchową pustkę, lęk i przygnębienie, utratę powodów, dla których warto żyć. Przyczyny są różnorakie. Z jednej strony praktyczny materializm bogatych, z drugiej strony materializm ideologiczny bądź otwarta walka z Bogiem (np. w krajach totalitarnych reżimów). Przyczyną jest także grzech, do którego kusi człowieka szatan, ojciec kłamstwa. Podpowiada mu, że może być rów-

9 Przemówienie inauguracyjne, 22 października 1978 r. www.opoka.org.pl/nauczanie/ papiez/jan_pawel_ii/przemowienia.php (17.02.2016).

10 Jan Paweł II, enc. Redemptor hominis, 7. 
ny Bogu i sam decydować o moralnych prawach. Jest to poniekąd próba wejścia człowieka w rolę Boga. Niekiedy jest to nie tyle zaprzeczanie istnieniu Boga, ile życie tak, jakby Boga nie było (Częstochowa 1991, Sydney 2008). Św. Jan Paweł II nazywa życie bez Boga największą iluzją (Toronto 2002). Stąd mocne wezwanie, by odkrywać na nowo wiarę, która pomoże odzyskać na nowo sens życia. Odkrycie wiary daje radość i nową energię duchową (Paryż 1997, Rio 2013). Widząc negatywne wpływy wskazanych trendów na młodzież, próby oderwania młodych od Boga, papieże zachęcają do budowania życia na solidnym fundamencie wiary i przyjaźni z Chrystusem. Sugerują, by patrzyła ona głębiej na świat doczesny i coraz bardziej uświadamiała sobie jego przemijalność, co otworzy ją na problem nieśmiertelności, a więc zwróci ku wierze. Przypominają dalej, że wiara chrześcijanina umacnia się, gdy jest przekazywana innym (Denver 1993, Sydney 2008). Benedykt XVI pokazuje elementarne, wypróbowane środki odkrywania wiary: poznawanie Pisma Świętego, katechizmu, udział w małych kościelnych wspólnotach, sakrament pokuty. Kościół jako taki jest środowiskiem kształtowania wiary (Kolonia 2005). Warto w tym miejscu zwrócić uwagę na podkreślenie radości odkrywania sakramentu pokuty zaznaczane też przez innych papieży. Zapewne wiąże się to ze zjawiskiem kryzysu tego sakramentu w wielu krajach, u którego podstaw stoi utrata poczucia grzechu ${ }^{11}$. Podobnie jest z niedzielną mszą świętą. Zjawisko zagubienia świętości niedzieli, absencji na niedzielnej mszy świętej jest z jednej strony konsekwencją zatracania wiary, z drugiej strony przyczyną dalszego pogłębiania kryzysu wiary. Stąd przypomnienie wartości niedzieli i niedzielnej Eucharystii. „Czas wolny bez Boga jest pusty" (Kolonia 2005, Rio 2013).

Wiara w Boga może jednak ulegać pewnym wypaczeniom. W wielu krajach zauważa się swoisty boom religijności, który jest odpowiedzią na pustkę duchową. Jednakże, jak mówi Benedykt XVI, religijność ta nierzadko jest wytworzona przez samych ludzi, na ich własne potrzeby, wygodna dla nich. Nie ma zakorzenienia w Bogu i nie jest rozumiana prawidłowo, jako Boży dar (łaska). Z tym wiąże się zjawisko prywatyzacji

11 Por. Jan Paweł II, list apost. Novo millenio ineunte, 51. 
i selektywizmu wiary. Papież zachęca, by młodzi odkrywali i pomagali innym odkrywać, że u początku wiary stoi sam Chrystus. Chrześcijanie nie poszukują „,prywatnych dróg”, które mogą ich poprowadzić w złym kierunku, ale razem we wspólnocie Kościoła idą ku Chrystusowi. Chrystusowy Kościół gwarantuje, że dojdą do pełnej prawdy (Kolonia 2005). Często papieże wskazują, że wypaczenie wiary jest skutkiem źle rozumianej wolności. Wynika to zapewne z obserwacji licznych sytuacji w świecie, w którym uważa się, że wolność polega na samowoli, nieliczeniu się z dobrem i trwałymi, uniwersalnymi zasadami moralnymi. Tak jak człowiek sam tworzy sobie boga, tak sam chce decydować o prawach moralnych. Wraz z wolnością utożsamianą z pełną swobodą i samowolą wielu ludzi odrzuca wiarę w Boga (Santiago 1989, Toronto 2002, Kolonia 2005, Sydney 2008).

\section{Kim jest człowiek?}

Papieże - co jest oczywiste - mówią nie tylko o wierze i relacji młodzieży do Chrystusa. W szeregu wypowiedzi koncentrują się na tym, kim jest człowiek. Zapytują młodych, czy dobrze budują swoje człowieczeństwo? Obserwują sytuację współczesnego człowieka i widzą, jak różnie rozumiane jest człowieczeństwo. Odnotowują jego fałszywe pojmowanie, lekceważenie człowieka i zagrożenie jego godności. Dlatego też zachęcają, by zbliżyć się do Chrystusa, wsłuchać się w Jego nauczanie i wpatrzyć się w Jego osobę. To pozwoli w pełni poznać tajemnicę człowieczeństwa, jego godność i powołanie dane mu przez Boga (Rzym 1985, Buenos Aires 1987). Chrystus pomaga młodym zrozumieć samych siebie (Santiago 1989). Przekonanie o wielkości i niepowtarzalności człowieka rodzi się stąd, że jest on stworzony przez Boga, Bóg jest jego Ojcem (Częstochowa 1991). Benedykt XVI zachęca także, by młodzież wpatrzyła się głęboko w świat i zobaczyła, że jest on naprawdę przesycony Bożą obecnością (Sydney 2008). A św. Jan Paweł II zachęca, by rozeznawała dobrze, czym została obdarowana przez Boga w Chrystusie. To obdarowanie pozwoli jej rozpoznać swoją ludzką wielkość (Buenos Aires 1987, Rzym 2000, Denver 1993). 
W czym jeszcze zawiera się ponadczasowe kryterium wielkości człowieka? Jan Paweł II zauważa, że młodzieży może zagrażać pokusa ze strony świata, który za kryterium kierujące postępowaniem człowieka przyjął panowanie nad innymi, władzę ekonomiczną pozwalającą uzależnić od siebie innych ludzi bądź „władzę nad kulturą”, by manipulować sumieniami innych. Istnieje pokusa, by tej władzy wręcz nadużywać. Na tym polega „duch tego świata”, którego niejednokrotnie odczuwa w sobie młodzież. Papież wskazuje, że ewangelicznym kryterium jest duch służby innym. „Być wielkim to znaczy służyć! Być człowiekiem dla drugich!” (Santiago 1989). Także i Franciszek podkreśla, że na wzór Jezusa życie młodych ma być życiem dla innych, przezwyciężaniem egoizmów zamykających na potrzeby innych i życiem posługi (Rio 2013).

Jan Paweł II zauważa też charakterystyczną cechę młodzieży, która nosi w sobie ambiwalencję. Młodzież jest krytyczna wobec świata dorosłych. Widzi wady świata i chciałaby go ulepszać. I jest to znaczący pozytyw. Krytyka może jednak przerodzić się w nieroztropny sprzeciw, który prowadzi młodych do „wyniosłego odosobnienia”. Stąd papież wzywa młodych, by uczyli się dialogu i porozumienia, zwłaszcza z rodzicami, i widzieli dobro, którym ubogaceni zostali przez dorosłe pokolenie (Manila 1995).

Pozytywną cechą młodzieży jest to, że szuka i pyta. Ta postawa pozwala im dobrze przejść przez życie, znajdować właściwe rozwiązania, a przede wszystkim dotrzeć do Boga (Denver 1993).

\section{Prawdziwa wolność}

Jedną z fundamentalnych cech człowieka jako istoty rozumnej i stworzonej na obraz Boży jest wolność. Jednakże, co często powtarza się w papieskim nauczaniu, nie tylko podczas Światowych Dni Młodzieży, wolność może być przez człowieka źle rozumiana. Papieże jasno podkreślają, że wolność nie jest jedynie uwolnieniem od obiektywnych norm, możliwością swobodnego działania, lecz jest możliwością realizacji dobra. Winna być zawsze poddana kryterium obiektywnej prawdy i stanowić realizację 
miłości. W szczególności nie polega ona na zerwaniu więzów z Bogiem, który jest dawcą moralnego prawa, by decydować o swym postępowaniu niezależnie od Niego (Rzym 1995, Buenos Aires 1987, Toronto 2002, Kolonia 2005, Sydney 2008).

Jan Paweł II przyznaje, iż „,wielu młodych sądzi, że są wolni, bo uwolnili się od wszelkiej kontroli i od wszelkich więzów odpowiedzialności”. Skoro widzą akceptację społeczną dla wielu etycznych nadużyć, uważają, że to usprawiedliwia ich nieetyczne postępowanie, a nawet sądzą, że jest ono właściwe. Niekiedy łamią obiektywne normy moralne pod wpływem mody lub tendencji nagłaśnianych przez media bądź pod naciskiem swoich rówieśników. Papież mówi wręcz o milionach „ofiar ukrytych, ale realnych form zniewolenia". Wymienia niektóre jego kształty: alkoholizm, narkomanię, seksizm, zepchnięcie w samotność egoizmu (Manila 1995). Wskazuje, że prowadzi to młodych do bezsensu, a nawet rozpaczy (Rzym 2000).

Zniewolenie bierze się niekiedy z wygodnictwa. Innym razem z lęku przed opinią społeczną bądź wysiłkiem koniecznym do pokonywania swoich słabości (Denver 1993). Stąd papieskie zachęty, by młodzi zwrócili się do Chrystusa, który pomoże im przezwyciężyć zniewolenia, zapanować nad sobą, pokonać fałszującego rzeczywistość, wspomnianego już wyżej, „ducha tego świata”, pokaże prawdziwą miłość, niewypaczoną przez „zabójczy i alienujący permisywizm”. Pozwoli zwyciężyć fałszywe złudzenia i zrezygnować z namiastek szczęścia. Papieskie nauczanie pokazuje zatem młodzieży, jak być panem samego siebie, a nie duchowym niewolnikiem (Rzym 1995, Buenos Aires 1987, Toronto 2002). Z drugiej strony jest zachęta do odwagi, by porzucić wygodny styl życia, „logikę hedonizmu”, a przyjąć „logikę krzyża i służby”, czyli umiejętności poświęcenia się dla innych (Rzym 2000). Odwagi, by przebijać się przez skorupę obojętności, duchowego znużenia i ślepego ulegania duchowi naszych czasów (Sydney 2008). Młodzi powinni jednocześnie dzielić się tą wolnością, którą odkryli, spotkawszy Jezusa Chrystusa, przekazując innym „wyzwalające orędzie Ewangelii” (Denver 1993). Dzięki ich apostolskiemu działaniu świat zniewolony złem może być dotknięty i uzdrowiony przez piękno i bogactwo Bożej miłości oraz stawać się bardziej uczłowieczony (Toronto 2002). 


\section{Młodzież a Kościół}

Papieże mają świadomość, że wśród młodzieży panuje postawa wyrażona w zdaniu: „Chrystus tak, Kościół nie”12. W papieskich przemówieniach podczas Światowych Dni Młodzieży nie pada wprost tego rodzaju stwierdzenie, choć można domyślić się, że zauważają w pewnej grupie młodzieży swoisty dystans i niepełne zaufanie do Kościoła. Generalnie jednak są przekonani, że młodzież kocha Kościół, jest z nim związana i uczestniczy w jego życiu, choć nie zna go jeszcze w pełni. Analizując papieskie wypowiedzi, trzeba wziąć pod uwagę, że uczestnikami Światowych Dni jest w większości młodzież wyselekcjonowana, bliska Kościołowi. Mimo to Benedykt XVI niejako na marginesie zauważa, że w niektórych kręgach młodzieży istnieje dystans do papieża i biskupów. Chce jednak przekonać młodzież, iż łączność z pasterzami Kościoła jest gwarantem, że chrześcijanie nie oddalą się od Chrystusa, „chodząc prywatnymi drogami", ale przeciwnie, będą w sposób pewny zbliżać się do Chrystusa (Kolonia 2005).

Papieże apelowali do młodzieży, by kochała Kościół, choć widzi w nim sytuacje gorszące (zapewne mieli na myśli grzechy członków Kościoła). Jednakże zapewniali, że Kościół ma ogromny potencjał świętości zrealizowanej przez wielu chrześcijan. Jest to świętość pochodząca od samego Boga. Słabości Kościoła są jeszcze większym wyzwaniem dla młodzieży, by sama dążyła do świętości i tak przezwyciężała zło (Toronto 2002). Stąd ważną rzeczą jest, by starała się poznać Kościół, jakim jest on naprawdę. Jest on Ciałem Chrystusa, darem od Boga, w którym działa Duch Święty. Kościół prowadzi nas do Boga, który jest najwyższą wartością. Nie jest on tylko ludzką instytucją. Owszem, potrzebuje odnowy i reformy. A to może się stać także dzięki szczeremu zaangażowaniu młodych (Sydney 2008, Madryt 2011). Papieże podkreślają, że człowiek młody potrzebuje Kościoła, bo w nim znajduje środki swojego wzrostu i rozwoju duchowego. Franciszek powtarza stwierdzenia swych poprzedników, że Kościół potrzebuje młodych, ich entuzjazmu, kreatywności i radości. Zapewnia

12 Por. np. M. Przeciszewski, Chrystus tak, Kościót nie?, http://www.deon.pl/religia/wiara-i-spoleczenstwo/art,20,chrystus-tak-kosciol-nie.html (01.08.2013). 
zarazem, że ilekroć podejmują oni misję ewangelizacyjną w świecie, nie są sami, bo jest razem z nimi cały Kościół. A przekonanie o tym czyni ich silnymi i odważnymi (Rio 2013).

\section{Entuzjazm i dynamika młodzieży. Nadzieja pokładana w młodych}

Jak zauważyliśmy wcześniej, papieże optymistycznie postrzegają współczesną młodzież. Tego generalnego spojrzenia nie zmienia fakt, że widzą wśród niej także negatywne zjawiska. Pozytywny obraz nie oznacza wcale, że papieże nie stawiają młodym wymagań.

Jan Paweł II wielokrotnie powtarzał, że młodzież jest nadzieją Kościoła i jego osobistą nadzieją. Mówi o niej, że jest „młodością Kościoła”, „Kościołem nadziei”, „Kościołem jutra”. Stało się to niemal hasłem przewodnim wszystkich jego przesłań do młodych. To zdanie znajduje odzwierciedlenie w przemówieniach podczas Światowych Dni Młodzieży (Częstochowa 1991, Rzym 2000, Toronto 2002). Przejęli je jego następcy, choć wyrażali w innych słowach. Tą nadzieją są wielki dynamizm ewangelizacyjny młodych, entuzjazm i poszukiwanie nowych dróg dzielenia się Ewangelią oraz odwaga. Młodzież może przyczynić się do odnawiania świata w duchu Ewangelii, ograniczania negatywnych zjawisk pojawiających się we współczesnym świecie. Może dotrzeć z przesłaniem Chrystusa do wielu środowisk, często zamkniętych na chrześcijańską wiarę. Przede wszystkim może wnieść wkład w działalność Kościoła i ciągle ją ożywiać (Manila 1995, Madryt 2011). Młode pokolenie nosi w sobie wartości, które będą owocować w przyszłości, przynosić odnowę Kościoła i w świata. Szczególną cechą środowiska młodych jest radość ich wiary i młodość ducha (Toronto 2002, Madryt 2011, Rio 2013). Zauważa się niekiedy w Kościele postawy skostnienia i braku pomysłów na ożywienie form jego działalności ${ }^{13}$. Wiarę przyjmuje się jako coś, co obciąża człowieka. Przez niejednego chrześcijanina jest ona postrzegana jedynie przez pryzmat moralnych wymagań i obowiązków. Nie zauważa się w niej czegoś,

13 Por. np. Franciszek, adhort. apost. Evangelii gaudium, 25. 
co daje radość ducha i umocnienie w różnorakich życiowych sytuacjach. Młodzież pomaga pokonać tego rodzaju postawy, które nie przyczyniają się do rozkrzewiania Ewangelii we współczesnym świecie.

Jan Paweł II był oczywiście świadomy, że młodzież napotyka w tym świecie sytuacje, które oddalają od chrześcijańskiej wiary i niszczą młodzieńcze ideały. Staje przed nią wiele trudności, które przeszkadzają i budzą lęki. Ale równocześnie był mocno przekonany, że nic nie zdoła „zdusić nadziei, która jest wiecznie żywa w sercach młodych ludzi” (Toronto 2002) oraz, że wystarczy młodym mądrości i męstwa w podejmowaniu trudnych wyzwań (Denver 1993).

Papieże domagają się jednak od młodych, by potrafili wobec świata „uzasadnić” nadzieję, która w nich jest (Buenos Aires 1987), a zatem by potwierdzali swoimi czynami i świadectwem to, o czym są głęboko przekonani. Wzywają, by nie tracili młodzieńczych ideałów, energii ducha i entuzjazmu. Proszą o rozpalanie ich ciągle na nowo. Kościół ciągle liczy na ożywcze wsparcie swojej misji ze strony młodych (Częstochowa 1991, Denver 1993, Madryt 2011).

Można przypuszczać, że właśnie to pozytywne odniesienie do młodzieży pozwoliło na zdobycie autorytetu przez papieży, co w odniesieniu do młodzieży nie jest łatwe. Także wymagania są chętniej przyjmowane, gdy towarzyszy im pozytywne odniesienie i zaufanie do głoszącego naukę. Młodzież zawsze była i jest krytyczna wobec świata - jest gotowa negować tradycyjne autorytety i akceptować nowe, osobiście wybrane. Wydaje się, że współcześnie to zjawisko jeszcze się wyostrza. Papieże potrafili pokonać te bariery.

\section{Misja młodych}

Posłanie młodych to bodajże drugi wątek najczęściej poruszany przez papieży. Oczywiście musimy wziąć pod uwagę, że w niniejszym artykule analizujemy przemówienia kończące kolejne Światowe Dni Młodzieży. $\mathrm{Z}$ natury zatem pojawia się w nich ten motyw.

Jan Paweł nazwał młodzież apostołami trzeciego tysiąclecia i zaadresował do nich słowa Chrystusa: „Wy jesteście solą ziemi i światłością 
świata” (Toronto 2002). A Benedykt XVI nazwał ich „nowym pokoleniem apostołów prowadzącym świat do Chrystusa" (Sydney 2008). Świat dzisiejszy potrzebuje świadectwa wiary ze strony młodych, bo mimo pozorów pragnie Boga (Madryt 2011). A Kościół liczy na ich ewangelizacyjne zaangażowanie (Rio 2013).

Jakjuż zauważyliśmy, papieże widzą w młodych dynamizm, chęć i radość dzielenia się Ewangelią z innymi. I jest to wielki pozytyw oraz podstawa do podejmowania konkretnych, szczegółowych zadań. Papieże wymieniają ich wiele. Trudno w ramach artykułu wyeksplikować wszystkie. Już wcześniej wskazywaliśmy szereg z nich. Dodajmy przykładowo: obronę życia i godności osoby ludzkiej, rozwój rodziny, sprawiedliwość, solidarność, pokój, pomoc najuboższym, troskę o ochronę środowiska naturalnego, wreszcie to, co papieże nazywali budowaniem cywilizacji miłości. Dalej także szerzenie społecznej nauki Kościoła (Częstochowa 1991, Denver 1993, Sydney 2008). Uzdrawianie sytuacji społecznych, które są źródłem cierpień i frustracji wielu ludzi (Manila 1995), pójście z Ewangelią do środowisk peryferyjnych, gdzie żyją ubodzy, do zobojętniałych religijnie, obalanie barier egoizmu, nietolerancji i nienawiści, budowanie nowego świata (Rio 2013). Papieże zwracają uwagę na bardzo szczególne zadanie, jakim jest włączenie się młodych w budzenie powołań kapłańskich i do życia konsekrowanego (Rzym 2000). Przy tym ostatnim nie można pominąć kryzysu powołań do stanu duchownego, który ogarnia zwłaszcza kraje bogatsze. Od wielkoduszności młodych i gotowości do poświęcenia się Bogu będzie zależało przezwyciężenie tego kryzysu.

Papieże przypominają teologiczne podstawy misji chrześcijan w świecie. Mówią do młodych, że skoro otrzymali dar poznania Chrystusa, to powinni się nim dzielić i przybliżać do wiary innych ludzi (Santiago 1989). Wszyscy bowiem ochrzczeni uczestniczą w posłannictwie Chrystusa. Każdy chrześcijanin ma w tym zadaniu swoją niepowtarzalną, właściwą sobie rolę. Ma ją także młodzież. Chrystus każdego uzdalnia do tej misji. Każdy otrzymał w tym celu dar Ducha Świętego. Papieże zachęcają młodych, by przyjęli „Jego wielką sprawę”. Zauważają, że młodzi potrafią się szczerze modlić i rozważać religijne kwestie. Te ostatnie są oczywiście ważne i stanowią podstawę wszelkiej apostolskiej aktywności. Ale młodzi nie mogą zatrzymać się tylko na medytacji i modlitwie. Potrzeba też 
czynu (Manila 1995, Sydney 2008). Chrześcijańskiego świadectwa oczekuje od młodych Kościół i cały świat (Rzym 1985, Buenos Aires 1987). Ważna jest już sama gotowość podjęcia misji (Denver 1993, Manila 1995). Uniwersalna misja Kościoła trwa stale, ale nie wszyscy chrześcijanie są przekonani co do konieczności osobistego udziału w niej. Dystansują się od niej, spychając to zadanie na innych, najczęściej na osoby duchowne. Młodzież powinna zrewidować to błędne przekonanie.

Wydaje się, że choć papieże widzą wielki zapał ewangelizacyjny młodych, to jednak zauważają pojawiający się niekiedy lęk przed dzieleniem się wiarą. Ten lęk może rodzić się ze wstydu bądź obawy przed prześladowaniem. Niewykluczone jednak, że ma on źródło w szerzącym się we współczesnym świecie przekonaniu, iż wiara jest sprawą prywatną. Chrześcijanin nie powinien więc nikomu jej narzucać. Z drugiej strony ma on podstawy w fałszywie rozumianej tolerancji dla wszelkich światopoglądów, w które nie powinien ingerować i z którymi nie powinien nawet dyskutować.

Głoszenie wiary nie jest jednak narzucaniem swoich poglądów i prozelityzmem, ale propozycją. Nie wynika z chęci panowania nad innymi. Jak już podkreśliliśmy wcześniej, papieże mówią o ukazywaniu przez młodych Chrystusa kochającego wszystkich ludzi i głoszącego prawdę, dzieleniu się tą miłością, której sami doznali ze strony Chrystusa, oraz zaproszeniu do wspólnoty z Nim (Rio 2013).

Następcy św. Piotra wzywają młodzież: nie bójcie się wyjść na ulice, do wsi i miast, aby jak apostołowie głosić Chrystusa. Nie czas wstydzić się Ewangelii (Denver 1993). Nie lękajcie się jej głoszenia. Z wami jest Chrystus i Kościół. To nie wy sami inicjujecie swą misję, to Chrystus was posyła. Jest to Jego misja. Gdy jesteśmy razem jako Kościół, jesteśmy mocni i nie obawiajmy się sprzeciwu ze strony innych oraz przeszkód. Jezus nie powołał apostołów do życia w izolacji, ale wezwał ich, aby tworzyli grupę, wspólnotę (Rio 2013).

Papież Jan Paweł II podkreśla, że to posłannictwo młodych ma dokonywać się w Kościele i przez Kościół, jest włączaniem w jego ewangelizacyjną działalność (Manila 1995). Być może jego wskazanie odzwierciedla zjawisko pewnej rezerwy wobec Kościoła, o której wspominaliśmy wcześniej. O ile młodzi chcą rozgłaszać Chrystusa, o tyle zdarza się, że czynią 
to niezależnie od Kościoła, własnymi drogami. A to może prowadzić do nieprawidłowych konsekwencji, kiedy to wierzący mijają się z Kościołem, a nawet tworzą pewne formy wiary „na własny użytek”.

Papieże zwracają też uwagę, że misją młodych jest na pierwszym miejscu wprowadzać innych do wspólnoty z Bogiem i uczestnictwa w życiu Trójcy Świętej, potem także do kościelnych wspólnot, ruchów i stowarzyszeń (Rzym 1985, Santiago 1989, Kolonia 2005, Madryt 2011). Jak się zdaje, chcą pośrednio zaznaczyć, że Kościół jest na pierwszym miejscu wspólnotą wertykalną, jednością z Bogiem. Nie powinien ograniczać swej działalności wyłącznie do aktywności horyzontalnej - co niekiedy zdarza się i jest zafałszowaniem jego priorytetów ${ }^{14}$.

Na koniec trzeba podkreślić to, o czym w różnych okolicznościach mówili papieże ostatnich dekad: najlepszymi ewangelizatorami młodych są sami młodzi, a wiara przekazywana innym umacnia się.

Autor artykułu ma świadomość, że nie wyczerpał wszystkich bogatych treści papieskich przesłań podczas Światowych Dni Młodzieży. Podkreśla to jeszcze raz, że papieże dawali młodym pozytywne wskazania. Niewiele mówili o tym, jaka ówczesna młodzież była, jednakże z ich wskazań można wnioskować, jak papieże postrzegali (postrzegają) współczesne młode pokolenie.

14 Por. np. Jan Paweł II, List Novo millenio ineunte, n. 38. 


\section{Summary}

\section{Młodzież w oczach papieży na podstawie przemówień podczas Światowych Dni Młodzieży}

Autor analizuje i komentuje treść przemówień papieży Jana Pawła II, Benedykta XVI i Franciszka wygłoszonych podczas trzynastu Światowych Dni Młodzieży. Ze względu na dużą liczbę papieskich wystąpień skupia się na przemówieniach podczas szczytowych spotkań. Autor chce odpowiedzieć na pytanie, jaki obraz współczesnej młodzieży przedstawiają w swych wystąpieniach papieże. W przemówieniach nie ma wprost opisu sytuacji młodzieży. Natomiast na podstawie poruszanej tematyki można pośrednio zorientować się, jakie zjawiska wśród młodzieży budzą nadzieję, a jakie niepokój. Ton papieskich wypowiedzi jest w większości wypadków pozytywny. Papieże widzą w młodzieży wiele dobrych cech, co budzi wielką nadzieję. Podkreślają konieczność nawiązywania przez młodych bliskich relacji z Chrystusem, budzenia wiary, która ma charakter osobistego spotkania z Bogiem. W świetle Ewangelii chcą uświadomić młodym pełną prawdę o człowieku, zwracają uwagę na sprawę prawidłowego rozumienia wolności, tłumaczą znaczenie Kościoła i relację chrześcijanina do Kościoła. Wreszcie akcentują dynamizm i entuzjazm młodzieży, zachęcają młodzież do podejmowania odpowiedzialności za misję ewangelizacyjną i apostolstwo.

Słowa kluczowe: Jan Paweł II, Benedykt XVI, papież Franciszek, Światowe Dni

Młodzieży, obraz współczesnej młodzieży

\section{Youth in the Popes' Eyes Basing on Speeches Given During World Youth Days}

The author analyses and comments on speeches given by the popes: John Paul II, Benedict XVI and Francis during thirteen celebrations of World Youth Days. Because of a great number of these he focuses mainly on the ones given during central events. The author aims to answer the question about the condition of the youth of today presented by the popes. Although there is no direct description of the situation of modern youth it can be concluded indirectly on the basis of discussed issues what phenomena among young people raise hope and which cause concern. In most cases tone of papal speeches is positive. Popes see good features in the youth what gives hope and they very rarely speak about negative aspects of lives of the young. A positive call is a response to a negative influence to which the current young generation is exposed. The popes put emphasis on the necessity of establishing close relationship with Christ by the youth and arousing within them faith having a nature of personal encounter with God. They want to realise young people the whole truth about human in the light of the Gospel, draw attention to proper understanding of freedom, explain 
the importance of the Church and relation a Christian to the Church. Finally, they stress dynamism and enthusiasm of the youth, encourage them to take responsibility for the evangelising mission and apostleship.

Keywords: John Paul II, Benedict XVI, Pope Francis, World Youth Day, condition of the youth of today

\section{Bibliografia}

Święty Jan Paweł II, Benedykt XVI, Franciszek, Do młodzieży (1979-2015). Listy, orędzia, przemówienia, homilie, Poznań 2015.

Benedykt XVI, Encyklika Deus caritas est.

Blachnicki F., Teologia pastoralna ogólna, Warszawa 2013.

Franciszek, Adhortacja Evangelii gaudium.

Jan Paweł II, List apostolski Novo millennio ineunte.

Jan Paweł II, Encyklika Redemptor hominis.

Przeciszewski M., Chrystus tak, Kościół nie?, http://www.deon.pl/religia/wiara-i-spoleczenstwo/art,20,chrystus-tak-kosciol-nie.html (01.08.2013). 